\title{
Variability of morphological needle traits of Scots pine (Pinus sylvestris L.) among populations from mountain and lowland regions of Poland
}

\author{
Bartosz Łabiszak ${ }^{1}$,Anetta Lewandowska-Wosik ${ }^{2}$,Ewa Maria Pawlaczyk ${ }^{2} \bowtie$, Lech Urbaniak ${ }^{2}$ \\ ${ }^{1}$ Adam Mickiewicz University in Poznań, Evolutionary Biology Group, Umultowska 89, 61-614 Poznań, Poland \\ ${ }^{2}$ Adam Mickiewicz University in Poznań, Department of Genetics, Umultowska 89, 61-614 Poznań, Poland, \\ e-mail: ewapaw@amu.edu.pl
}

\section{Abstract}

The main goal of this work was to examine interpopulational needle traits variability of Scots pine (Pinus sylvestris L.) from four mountain, one foothill and three lowland, natural populations located in Poland. This choice of locations was motivated by the presumed different origins of mountainous populations and the necessity to demonstrate how closely they are related to lowland populations.

Variation in the studied populations was determined using seven morphological traits of needles: 1 - needle length, 2 - number of stomatal rows on the flat side of a needle, 3 - number of stomata per $2 \mathrm{~mm}$ of needle length on the flat side, 4 - number of stomatal rows on the convex side of a needle, 5 - number of stomata per $2 \mathrm{~mm}$ of needle length on the convex side, 6 - number of serrations per $2 \mathrm{~mm}$ of the needle length on the left side and 7 - number of serrations per $2 \mathrm{~mm}$ of the needle length on the right side.

Biometric data were analysed statistically, and it was found that (i) needle traits differentiate studied populations; (ii) the postulated division of the population into two groups is reflected in the obtained results; and (iii) a particularly strong relationship was found between two relict pine populations from the Pieniny (Sokolica, Kazalnica, Czertezik) and Tatra Mts. (Wielke Koryciska), which may be the result of the common origins and history of these two populations.

\section{KEY WORDS}

conifers, interpopulational variation, relict population, morphometric, stomata

\section{INTRODUCTION}

Scots pine (Pinus sylvestris L.) is a common Eurosiberian species. Its range across Eurasia exhibits characteristic features of regular, even distribution, with a number of island stands, particularly on the edge, where they are often completely isolated (Szafer 1949; Boratyński 1993). The longitudinal range of Scots pine covers a distance of over $14,000 \mathrm{~km}$, while latitudinal range stretches between $72^{\circ} \mathrm{N}$ in Norway and $37^{\circ} \mathrm{N}$ in Sierra Nevada in Spain, giving a total spread of $2700 \mathrm{~km}$ (Białobok 1970; Boratyński 1993; Urbaniak 1998). The optimum 
growth conditions for Scots pine are found in the centre of its range, especially in Poland. Here, it is one of the most common tree species and occupies almost $70 \%$ of the total forest area, thus being an essential component of almost all large forest complexes (Boratyński 1993).

The clear dominance of pine in Poland is expressed only in the lowlands, while in the southern parts, e.g. in the Carpathian and Sudetes foothills, its distribution takes the form of irregular, patchy and usually completely isolated stands (Androsiuk and Urbaniak 2006). Mountain populations of Scots pine in Poland show considerable distinction from lowland populations, expressed, among other things, by habitat specificity and a unique set of genetic and morphological traits. In principle, these populations are very small (e.g. in the Pieniny - from a few individuals up to a few hundred) and grow in specific habitats on small rocks or raised bogs (Zajączkowski 1936; Jasiewicz 1965; Boratyński 1978). Such uniqueness is closely related to the presumably relict origins of these populations, as has been hypothesized by others (Androsiuk and Urbaniak 2006; Urbaniak 2006; Urbaniak and Vončina 2008). Although it is known that the most important glacial refugia of Scots pine are located on the Iberian Peninsula, the Balkans and Italy (Cheddadi et.al. 2006), it is conceivable that aside from the main refugial area pine could have probably survived in smaller refugia in other parts of Eurasia, including the Pieniny and Tatra Mountains (Wielkie Koryciska and Małe Koryciska) (Staszkiewicz 1993; Ralska-Jasiewiczowa 2004 Naydenov et al. 2007; Pyhäjärvi et al. 2008) and also as it is suggested in a recent extensive study of 92 Scots pine population based on mtDNA and cpSSR, there is a possibility of existence cryptic northern refugia, which can explain discordance with the phenomenon of "southern richness and northern purity" observed in this population (Dering et al. 2017).

There have been limited reports focusing on interpopulational variation of Scots pine in natural habitats in different parts of Poland based on morphological needle traits. These studies have generally taken into account populations from contrasting habitats, separated by only short geographical distances (Woźniak et al. 2005; Urbaniak et al. 2003; Pawlaczyk et al. 2010), or populations that are particularly interesting due to the fact of their hypothesized relict origins (Androsiuk and Urbaniak 2006; Urbaniak et al. 2006; Urbaniak and Vončina 2008).
The main objective of this work was therefore to illustrate the wider geographical aspect of Scots pine differentiation in Poland. Our attempt to demonstrate whether populations originating from mountain regions and from lowland regions are distinct from each other is also important. Such a division is motivated by the presumed different origins of mountain populations, and therefore it is necessary to demonstrate how closely they are related to lowland populations.

\section{MATERIALS AND METHOdS}

The research material for biometric and statistical analysis was obtained from eight Scots pine populations from different locations in Poland. Three of them came from mountains, four from lowlands and one from foothill regions. The exact location of these populations is shown in Fig. 1. The mountain populations were collected in the following locations: Tatra Mts. (Wielkie Koryciska - M1), Pieniny Właściwe Mts. (collective population from Sokolica, Kazalnica and Czertezik - M2), and Stołowe Mts. (Szczeliniec Wielki - M3), while lowland populations were from Słowiński National Park (Czołpino - L1, and Czerwona Szopa - L2), Vistula Spit (Piaski - L3) and Wielkopolska National Park (Zalewy Nadwarciańskie - L4). The foothill population was from Tatra Mts. foothills (Puścizna near Chyżne - FH1). Although, due to complex history of this species in Poland, we cannot be certain about their natural origin, but knowing that they came from highly isolated and remote stands (M1, M2, M3,FH1), from conservational area (L1, L2, L4) or outside main area of human activity (L3), it is likely to assume their natural or at least semi-natural origin. Those stands differ with respect to types of forest community (from lone trees on the edge of horizontal range of species and dominant in lowlands Leucobryo-Pinetum forest, to coastal Empetro nigri-Pinetum), and also with respect to types of soils (rendzina soil on the limestone in mountains and podsolic on sands in other stands). We investigated two-yearold needles, harvested from 30 randomly selected individuals from each population (except for populations Szczeliniec Wielki, Piaski and Czołpino - represented respectively by 17,20 and 27 individuals). In each study area $300 \mathrm{~m}$ long linear transect was established and every $10 \mathrm{~m}$ needles from one tree were sampled. From each 
individual, we cut down 10 long shoots from middle part of crown, and for each long shoot we choose only one needle to further measurements - resulting in 10 measurements per specimen and ca. 300 total measurements per population. Needles were measured using a stereo microscope at $40 \times$ magnification. Each needle was analysed for the following morphological traits: (1) needle length in $\mathrm{mm}(\mathrm{NL})$; (2) number of stomatal rows on the flat side of the needle (NRF); (3) number of stomata per $2 \mathrm{~mm}$ of needle length on the flat side (NSF); (4) number of stomatal rows on the convex side of the needle (NRC); (5) number of stomata per $2 \mathrm{~mm}$ of needle length on the convex side (NSC); (6) number of serrations per $2 \mathrm{~mm}$ of the needle length on the left

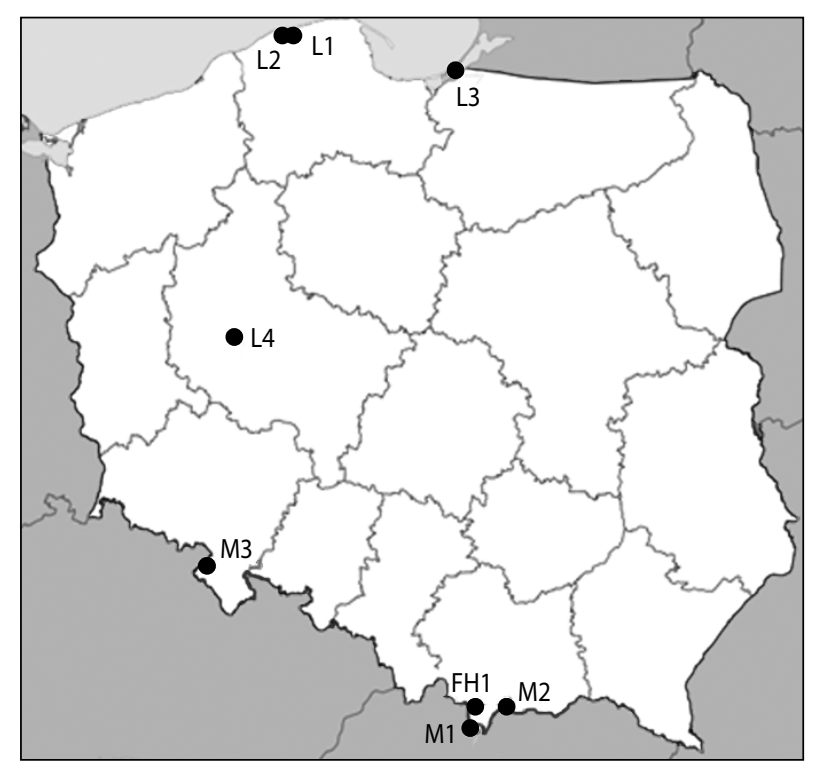

\begin{tabular}{|c|c|c|c|}
\hline $\begin{array}{c}\text { Population } \\
\text { code }\end{array}$ & Latitude N & Longitude E & $\begin{array}{c}\text { Altitude } \\
\text { m a.s.I }\end{array}$ \\
\hline L1 & $54^{\circ} 70^{\prime} 67^{\prime \prime}$ & $17^{\circ} 30^{\prime} 65^{\prime \prime}$ & 2 \\
\hline L2 & $54^{\circ} 72^{\prime} 00^{\prime \prime}$ & $17^{\circ} 21^{\prime} 94^{\prime \prime}$ & 6 \\
\hline L3 & $54^{\circ} 39^{\prime} 03^{\prime \prime}$ & $19^{\circ} 46^{\prime} 20^{\prime \prime}$ & 14 \\
\hline L4 & $53^{\circ} 31^{\prime} 04^{\prime \prime}$ & $16^{\circ} 89^{\prime} 33^{\prime \prime}$ & 60 \\
\hline FH1 & $49^{\circ} 43^{\prime} 71^{\prime \prime}$ & $19^{\circ} 70^{\prime} 72^{\prime \prime}$ & 653 \\
\hline M1 & $49^{\circ} 26^{\prime} 94^{\prime \prime}$ & $19^{\circ} 81^{\prime} 00^{\prime \prime}$ & 1020 \\
\hline M2 & $49^{\circ} 41^{\prime} 75^{\prime \prime}$ & $20^{\circ} 44^{\prime} 06^{\prime \prime}$ & 737 \\
\hline M3 & $50^{\circ} 48^{\prime} 58^{\prime \prime}$ & $16^{\circ} 33^{\prime} 92^{\prime \prime}$ & 860 \\
\hline
\end{tabular}

Figure 1. Localization of studied populations in Poland with latitude, longitude and altitude of each stand (see text for details) side (SL); and (7) number of serrations per $2 \mathrm{~mm}$ of the needle length on the right side (SR).

The biometric data were then processed, and the following statistical tests were performed on averaged values for each individual: basic descriptive statistics (mean, minimum and maximum, standard deviation, variation coefficient, skewness and curtosis); Pearson correlation coefficients; one-way ANOVA; Tukey's honest significant difference (HSD) test; discriminant function analysis with Mahalanobis distances; Mantel test (Mantel 1967); and cluster analysis using Ward's method based on Euclidian distances using standardized data. All statistical computations were made using STATISTICA 10.0 software (StatSoft), except Mantel test computed using GenAlEx (Peakall and Smouse 2006).

\section{Results}

The summary of the basic descriptive statistics of all morphological needle traits (Tab. 1) shows that variability in the studied populations, expressed by variation coefficient, is not lower than $3.14 \%$ and not greater than $25.85 \%$. The most stable traits were NSF and NSC as suggested by the lowest value of variation coefficient (with range from $3.14 \%$ to $6.41 \%$ ). Other morphological traits were much more variable, and of those, NL was the most variable. The average variability of needle length for all populations was $15.86 \%$; the highest variability was seen in L1 population (19.67\%), whereas the lowest variability was seen in the M1 population (13.68\%) (Tab. 1).

The comparison of the arithmetic means for all observed traits in each population (Tab. 1) revealed that FH1 population had the highest values for all of them, except for NL (needle length). It is noteworthy that the means of the most stable traits, described by the number of stomata on $2 \mathrm{~mm}$ of needle length, both on flat and convex sides (NSF and NSC, respectively), only slightly differentiated the studied populations (Tab. 1). On the other hand, more variable pairs of features, i.e. NRFNRC (describing the number of stomatal rows on both sides of the needle) and SL-SR (describing the number of serrations on both edges of the needle), indicated differences among populations, and it was surprising that the number of serrations on both sides of the needle was similar in populations: M1, M2 and L4. However, it should be noted that these features distinguished them 
only slightly from populations: L1, L3 and M3. Lastly, it should be mentioned that in terms of the number of stomatal rows on both sides of the needle, the M1 and M2 populations were strikingly similar, and at the same time they had the lowest possible averages.

Table 1. Basic statistics for seven morphological needle traits

\begin{tabular}{|c|c|c|c|c|c|c|c|c|}
\hline 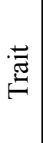 & 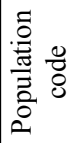 & 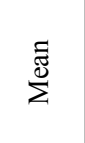 & 志 & 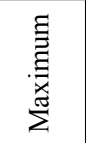 & 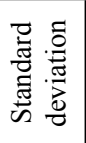 & 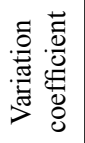 & 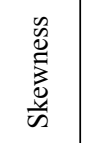 & 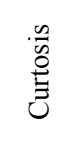 \\
\hline 1 & 2 & 3 & 4 & 5 & 6 & 7 & 8 & 9 \\
\hline \multirow{8}{*}{ 之 } & FH1 & 34.80 & 25.70 & 45.90 & 5.20 & 14.95 & 0.42 & -0.39 \\
\hline & L1 & 39.02 & 26.10 & 64.00 & 7.68 & 19.67 & 1.28 & 3.12 \\
\hline & L2 & 52.98 & 35.20 & 72.40 & 9.48 & 17.89 & 0.34 & -0.33 \\
\hline & L3 & 54.65 & 35.30 & 65.00 & 7.81 & 14.29 & -0.53 & 0.29 \\
\hline & L4 & 71.76 & 45.20 & 93.30 & 10.19 & 14.19 & -0.06 & 0.54 \\
\hline & M1 & 34.66 & 24.40 & 44.30 & 4.74 & 13.68 & 0.10 & -0.31 \\
\hline & M2 & 35.26 & 25.00 & 48.70 & 5.59 & 15.86 & 0.36 & -0.03 \\
\hline & M3 & 35.87 & 25.80 & 43.00 & 5.87 & 16.36 & -0.26 & -1.32 \\
\hline \multirow{8}{*}{$\begin{array}{l}\cup \\
\check{z} \\
Z\end{array}$} & FH1 & 10.79 & 8.60 & 13.10 & 1.05 & 9.70 & -0.25 & -0.08 \\
\hline & L1 & 9.37 & 8.20 & 11.50 & 0.82 & 8.76 & 0.89 & 0.79 \\
\hline & L2 & 10.42 & 8.50 & 13.10 & 1.18 & 11.29 & 0.41 & 0.35 \\
\hline & L3 & 9.81 & 7.90 & 11.50 & 0.91 & 9.27 & -0.13 & -0.26 \\
\hline & L4 & 9.50 & 6.90 & 12.00 & 1.29 & 13.55 & -0.26 & -0.45 \\
\hline & M1 & 8.44 & 7.00 & 10.20 & 0.86 & 10.16 & 0.19 & -0.83 \\
\hline & M2 & 8.41 & 7.00 & 10.50 & 0.88 & 10.51 & 0.26 & -0.26 \\
\hline & M3 & 9.22 & 8.30 & 10.50 & 0.54 & 5.86 & 0.50 & 0.67 \\
\hline \multirow{8}{*}{$\frac{1}{z}$} & FH1 & 9.24 & 5.90 & 11.60 & 1.21 & 13.15 & -0.68 & 1.11 \\
\hline & L1 & 8.06 & 6.60 & 9.90 & 0.84 & 10.41 & 0.38 & -0.39 \\
\hline & L2 & 9.05 & 7.10 & 11.90 & 1.01 & 11.13 & 0.04 & 1.11 \\
\hline & L3 & 8.63 & 7.70 & 9.60 & 0.63 & 7.27 & -0.05 & -1.35 \\
\hline & L4 & 7.92 & 5.60 & 10.20 & 1.11 & 14.02 & 0.15 & -0.38 \\
\hline & M1 & 6.83 & 5.70 & 880 & 0.81 & 11.85 & 0.51 & -0.49 \\
\hline & M2 & 6.89 & 5.40 & 9.50 & 0.86 & 12.48 & 0.86 & 1.68 \\
\hline & M3 & 8.02 & 6.30 & 0.90 & 0.64 & 7.95 & -1.17 & 2.24 \\
\hline \multirow{8}{*}{$\begin{array}{l}U \\
\mathscr{Z} \\
\text { 乙 }\end{array}$} & FH1 & 24.73 & 22.05 & 27.05 & 1.19 & 4.82 & 0.31 & 0.16 \\
\hline & L1 & 21.61 & 20.20 & 23.60 & 0.83 & 3.85 & 0.96 & 0.96 \\
\hline & L2 & 22.77 & 19.95 & 25.50 & 1.40 & 6.14 & 0.12 & -0.40 \\
\hline & L3 & 22.93 & 21.65 & 24.45 & 0.80 & 3.50 & 0.39 & -0.61 \\
\hline & L4 & 22.19 & 19.75 & 24.20 & 1.10 & 4.95 & -0.15 & -0.29 \\
\hline & M1 & 22.26 & 20.60 & 27.05 & 1.33 & 5.96 & 1.75 & 4.78 \\
\hline & M2 & 22.32 & 20.50 & 24.95 & 1.13 & 5.05 & 0.40 & -0.04 \\
\hline & M3 & 21.32 & 20.45 & 22.55 & 0.67 & 3.14 & 0.53 & -0.63 \\
\hline
\end{tabular}

\begin{tabular}{|c|c|c|c|c|c|c|c|c|}
\hline 1 & 2 & 3 & 4 & J & 6 & 7 & 8 & 9 \\
\hline \multirow{8}{*}{$\begin{array}{l}\text { 岕 } \\
\text { 乙 }\end{array}$} & FH1 & 25.22 & 20.42 & 45.40 & 4.01 & 4.56 & 4.63 & 24.01 \\
\hline & L1 & 2146 & 19.65 & 36 & 0 & 4.42 & 0.5 & 0.14 \\
\hline & L2 & 22.96 & 20.65 & 25.55 & 1.26 & 5.48 & 0.17 & -0.20 \\
\hline & L3 & 24.03 & 21.55 & 43.70 & 4.72 & 5.38 & 4.21 & 1.84 \\
\hline & L4 & 22.51 & 20.25 & 24.55 & 0.98 & 4.37 & -0.15 & 0.09 \\
\hline & M1 & 22.65 & 19.90 & 27.75 & 1.45 & 6.41 & 1.35 & 4.08 \\
\hline & M2 & 22.56 & 20.50 & 24.80 & 1.04 & 4.62 & 0.25 & -0.49 \\
\hline & M3 & 21.07 & 19.55 & 23.10 & 0.94 & 4.44 & 0.21 & -0.07 \\
\hline \multirow{8}{*}{$\ddot{n}$} & FH1 & 9.69 & 7.60 & 13.50 & 1.13 & 11.71 & 1.09 & 3.18 \\
\hline & L1 & 8.28 & 6.90 & 11.40 & 1.06 & 12.84 & 1.07 & 1.20 \\
\hline & L2 & 8.97 & 6.70 & 10.60 & 1.01 & 11.23 & -0.77 & -0.02 \\
\hline & L3 & 8.36 & 7.20 & 10.40 & 0.87 & 10.42 & 0.91 & 0.13 \\
\hline & L4 & 7.72 & 5.80 & 10.10 & 1.08 & 14.01 & 0.12 & -0.73 \\
\hline & M1 & 7.90 & 6.30 & 10.70 & 0.99 & 12.50 & 0.55 & 0.77 \\
\hline & M2 & 7.61 & 5.50 & 9.10 & 0.73 & 9.53 & -0.44 & 1.36 \\
\hline & M3 & 8.19 & 6.70 & 9.60 & 0.79 & 9.65 & -0.43 & 0.05 \\
\hline \multirow{8}{*}{$\frac{\mathscr{4}}{\mathscr{W}}$} & FH1 & 10.24 & 8.40 & 13.60 & 1.16 & 11.33 & 0.92 & 1.24 \\
\hline & L1 & 9.00 & 7.50 & 12.10 & 1.15 & 12.79 & 1.04 & 0.74 \\
\hline & L2 & 9.16 & 7.40 & 10.50 & 0.76 & 8.29 & -0.33 & -0.55 \\
\hline & L3 & 8.99 & 7.60 & 18.20 & 2.32 & 25.85 & 3.62 & 1.44 \\
\hline & L4 & 7.82 & 6.40 & 9.80 & 1.03 & 13.15 & 0.43 & -0.94 \\
\hline & M1 & 8.07 & 6.40 & 9.60 & 0.92 & 11.42 & -0.23 & -0.96 \\
\hline & M2 & 7.97 & 6.30 & 9.20 & 0.63 & 7.87 & -0.52 & 0.79 \\
\hline & M3 & 8.53 & 7.00 & 9.90 & 0.83 & 9.75 & -0.19 & -0.70 \\
\hline
\end{tabular}

$\mathrm{NL}$ - length of the needles [mm]; NRF - number of stomata rows on the flat sides of the needles; NSF - number of stomata per $2 \mathrm{~mm}$ length on the flat sides of the needles; NRC - number of stomata rows on the convex sides of the needles; NSC - number of stomata per $2 \mathrm{~mm}$ length on the convex sides of the needles; SL - number of serrations per $2 \mathrm{~mm}$ of the needle length on the right edges; SR - number of serrations per $2 \mathrm{~mm}$ of the needle length on the left edges.

Table 2. Values of $\mathrm{F}$ - Snedecor's statistics ( $\mathrm{p}$ value $<0.05$ )

\begin{tabular}{|c|c|c|}
\hline Trait & $F$ value & $p$ \\
\hline NL & 96.71 & 0.00 \\
\hline NRF & 26.74 & 0.00 \\
\hline NSF & 8.35 & 0.00 \\
\hline NRC & 21.61 & 0.00 \\
\hline NSC & 23.24 & 0.00 \\
\hline SL & 14.84 & 0.00 \\
\hline SR & 14.47 & 0.00 \\
\hline
\end{tabular}

After checking normality of data using ShapiroWilk (not shown), we performed one-way ANOVA 
Table 3. Results of Tukey's HSD test for the seven studied traits in eight populaions
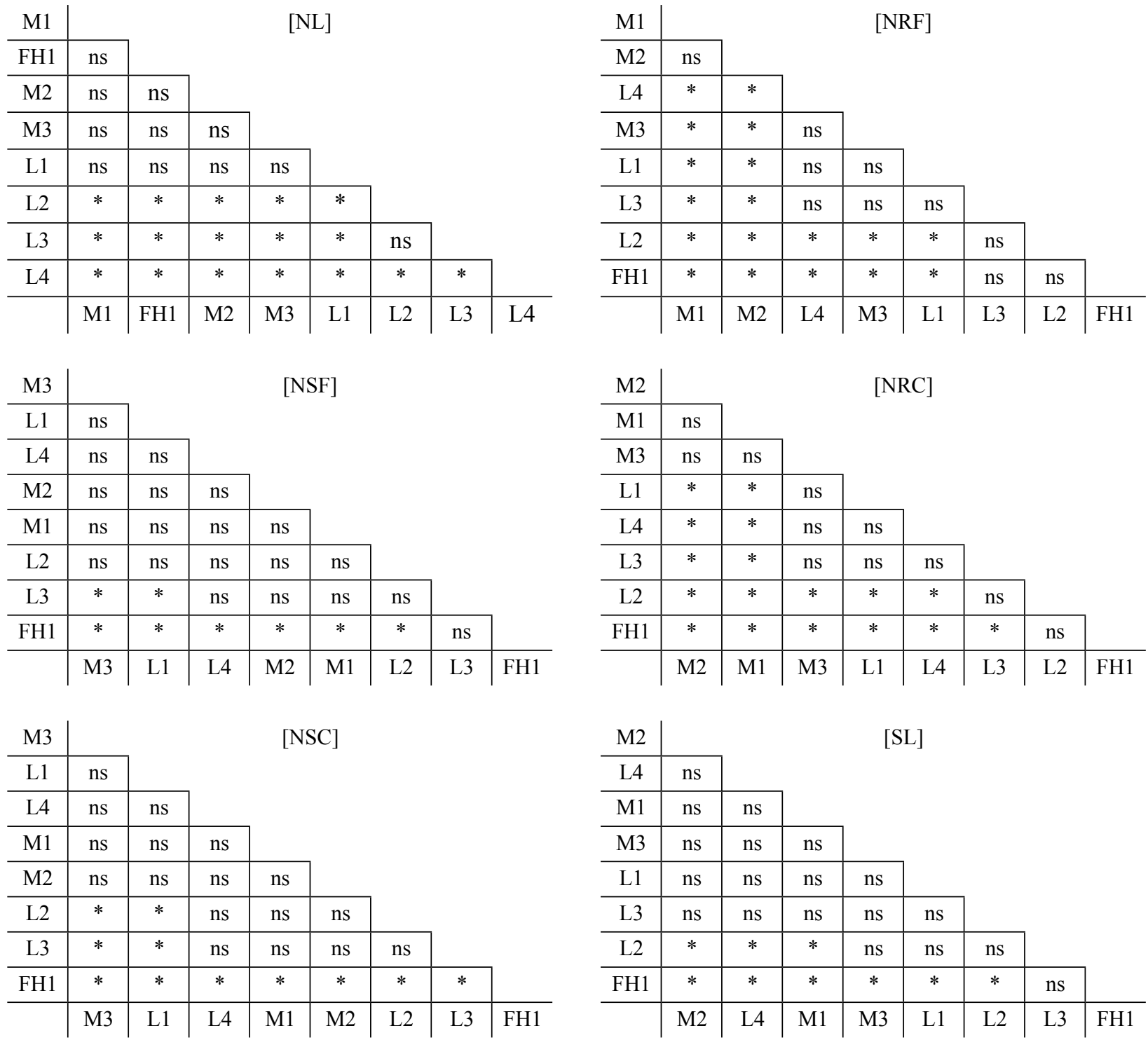

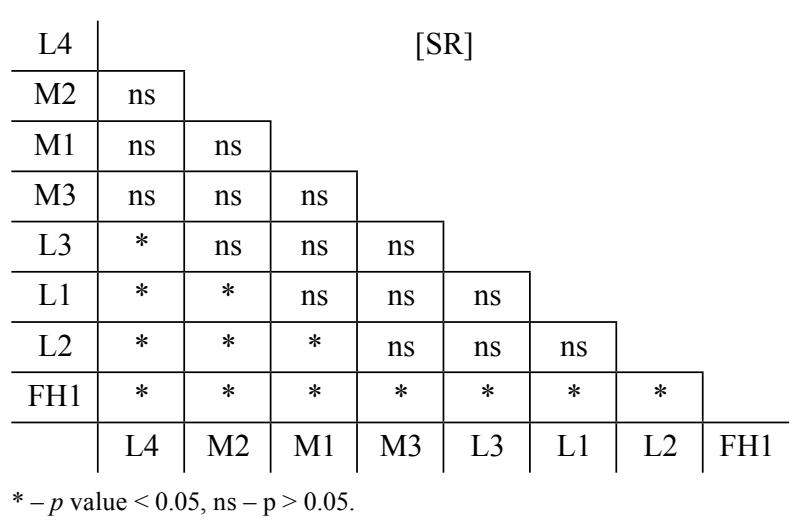

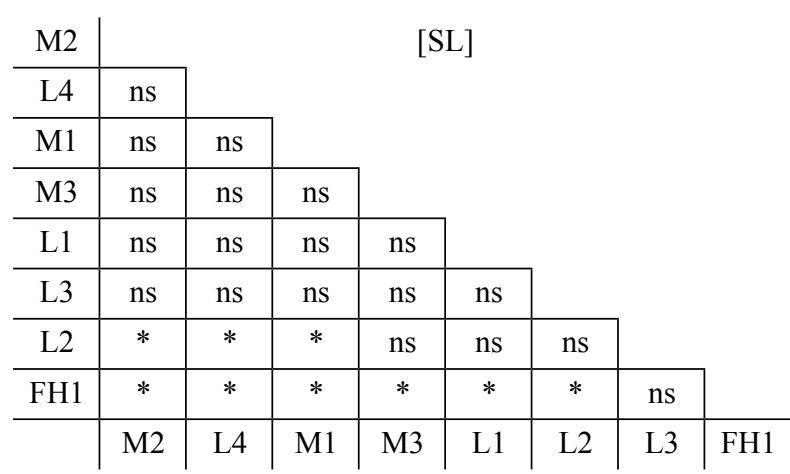


test, which proved that all of the tested morphological needle traits differentiate populations in a statistically significant way (Tab. 2). The highest degree of variation was found for NL $(F=96.71, p<0.001)$. Differentiation of populations, although to much lesser extent, indicate NRF (number of stomatal rows on the flat side of a needle), NSC and NRC ( $F=26.74,23.24$ and 21.61 respectively). NSF had the smallest influence on interpopulational differentiation $(F=8.35)$.

The results of Tukey's HSD test are shown in Table 3. The average value of NL (needle length), with the greatest influence on differentiation among the studied populations, also supported the formation of three distinct groups of populations. The first group consisted of populations FH1, M1, M2 L1 and M3 and the second of populations L2 and L3. Population L4 was significantly different from other populations, and thus was completely separated from them (Tab. 3). The pattern for other morphological traits was much less clear. Only NRF, NSC and SR allowed the division of the studied populations into groups. Populations M1 and M2 were separated from other populations with regard to NRF, whereas both NSC and SR indicated the complete separateness of population FH1.

Given the calculated coefficients of determination between the measured traits of needles and the first two discriminant variables $U_{1}$ and $U_{2}$ (Tab. 4), the trait with the biggest influence on the obtained pattern of variability was determined. NL had the biggest influence on the first discriminant variable $U_{1}$, while the second discriminant variable $\mathrm{U}_{2}$ was determined mainly by NRF and NRC.

Table 4. Coefficients of determination among 7 traits of needles and the first three discriminant variables

\begin{tabular}{|c|c|c|}
\hline Trait & $\begin{array}{c}\mathrm{U}_{1} \\
(75.88 \%)\end{array}$ & $\begin{array}{c}\mathrm{U}_{2} \\
(19.32 \%)\end{array}$ \\
\hline $\mathrm{NL}$ & 66.81 & 1.31 \\
\hline $\mathrm{NRF}$ & 0.13 & 10.57 \\
\hline $\mathrm{NSF}$ & 0.01 & 0.52 \\
\hline $\mathrm{NRC}$ & 0.13 & 9.25 \\
\hline $\mathrm{NSC}$ & 0.43 & 6.01 \\
\hline $\mathrm{SL}$ & 0.64 & 5.05 \\
\hline $\mathrm{SR}$ & 0.51 & 2.34 \\
\hline
\end{tabular}

The distribution of populations in the plane of the first two discriminant variables $\left(\mathrm{U}_{1}\right.$ and $\left.\mathrm{U}_{2}\right)$ represent a total of $95.15 \%$ of the information contained in variation within the seven studied morphological traits (Fig. 2) and emphasizes the separation between two groups of populations and the presence of two isolated populations outside of those groups. The first group included populations M1, M2, M3 and L1, while the second consisted of two populations, L2 and L3. Populations FH1 and L4 demonstrated individual traits and were located outside other groups. Additionally, the Mahalanobis distances were calculated and the minimum spanning tree was drawn. The smallest distances were between mountain populations (M1-M3), and between M3 and one population from lowland (L1), whereas the major distance was discovered between lowland population (L1) and foothill stand (FH1). Great Mahalanobis distance was found also between two lowland populations (L3 and L4) (Fig. 2).

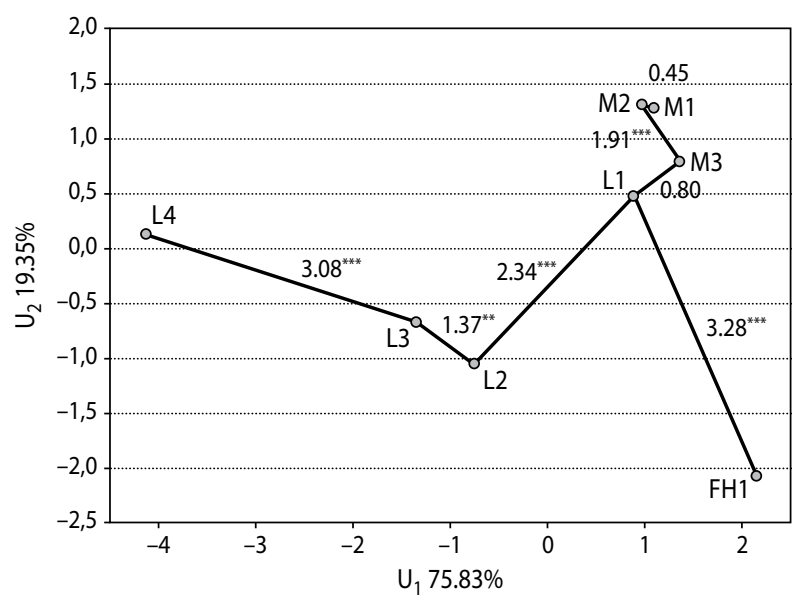

Figure 2. The result of the discriminant analysis on the plane of the first two discriminant variables obtained from the seven morphological needle traits with minimum spanning tree constructed on the basis of the shortest Mahalanobis distances $(* p<0.05 ; * * p<0.01 ; * * * p<0.001)$

Mantel test did not detect the correlation between geographical and biological (Mahalanobis) distances among stands $(r=0.02 ; p=0.370)$.

The cluster analysis was carried out in three steps. Initially, a dendrogram included all seven morphological needles traits (Fig. 3A). Then, NL was omitted (Fig. 3B) and the dendrogram was constructed. The third dendrogram was based only on traits associated 
with stomata (Fig. 3C). We used this procedure to evaluate the impact of traits considered to be responsive to environmental modifications on the overall pattern of interpopulational differentiation.

\section{A}

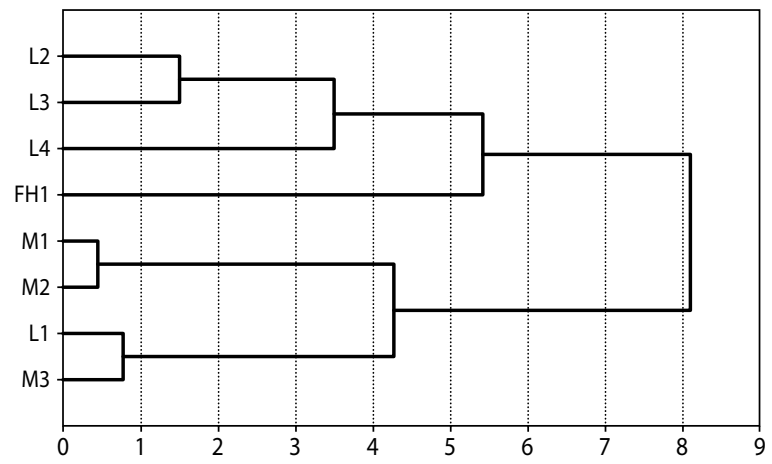

B

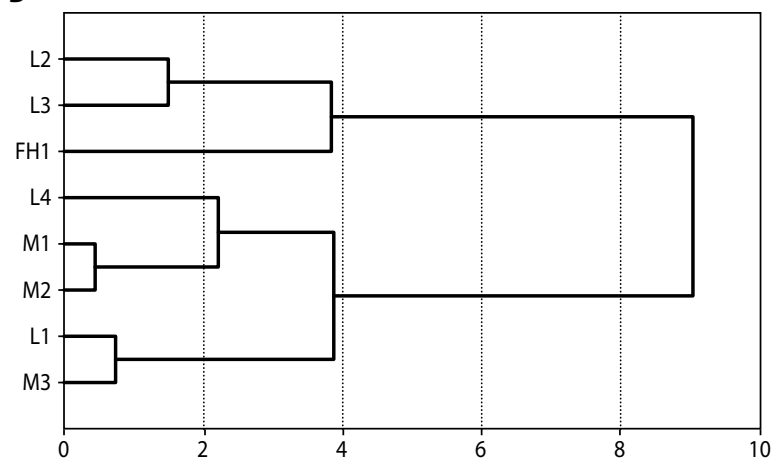

C

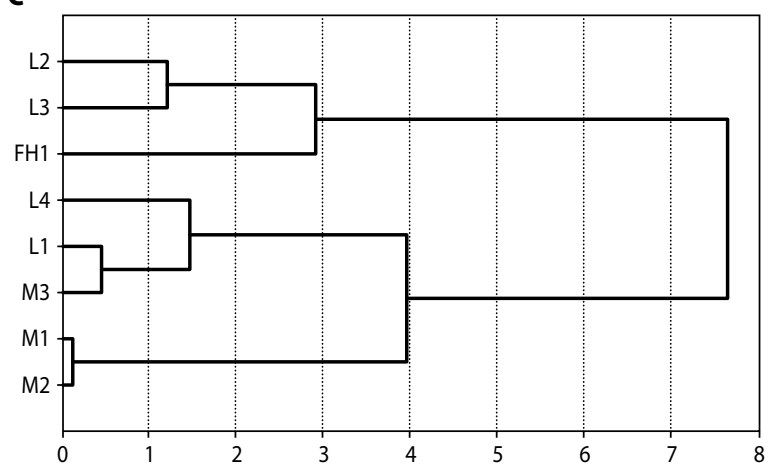

Figure 3. Dendrograms generated by the cluster analysis of eight Scots pine populations using Ward's method based on Euclidean distance using standardized data: A based on 7 morphological traits of needles, B - based on 6 morphological traits of needles (NL omitted), $\mathrm{C}$ - based on 4 morphological traits of needles (NRF, NSF, NRC, NSC)
All the presented dendrograms show a clear division of the studied populations into two distinct groups. However, depending on whether NL (needle length) was considered or not, these groups were slightly different (e.g. population L4 was either in one or the other group). The dendrogram for all needle traits (Fig. 2) presents two groups. One of them consist of populations M1, M2, M3 and L1 - the group with the majority of mountain populations; and the other of populations L2, FH1, L4 and L3 - the group of lowland population, except for population FH1.

\section{Discussion}

Studies on the differentiation of Scots pine on the basis of morphological needle traits have their own particular limitation. They result mainly from the different susceptibility of those traits to environmental factors (Żelawski and Gowin 1966, Irvine et al. 1998, Niinemets et al. 2001, Urbaniak et al. 2003). Paying special attention to these kind of aspects related to differentiation is crucial in our case - comparisons of populations originating from contrasting natural habitats. In addition, the rich history of this species in Poland should also be considered, especially in two key aspects. First of them is the history of Scots pine on Polish territory, both during and after the last glacial period (Staszkiewicz 1968, Obidowicz 1996, Urbaniak 1998, Ralska-Jasiewiczowa 2004, Androsiuk et al. 2011). The second and currently most important aspect that has to be taken into account is the mixing of different populations as a consequence of using seeds of unknown origin in reforestation. It is worth noting that it significantly complicates comparisons of populations and the assessment of their diversity (Oleksyn and Rachwał 1994).

In our study, needle length had the greatest observed influence on the interpopulational variation among all traits. This is consistent with the studies of other authors (Urbaniak et al. 2003, Woźniak et al. 2005, Pawlaczyk et al. 2010). This trait, despite the considerable susceptibility to environmental influences in the comparative plantations, maintains its characteristic value (Żelawski and Gowin 1966, Androsiuk et al. 2011). On the basis of this trait, in Tukey's HSD test, we obtained a pattern of the division of the studied populations into three distinct groups: mountain 
populations (M1, M2, M3, FH1) with one population from the Baltic coast (L1); typical coastal populations (L2, L3) and a lowland population (L4) (Tab. 3.). These results also correlate well with Ward's dendrogram based on all the morphological needle traits (Fig. 3A). There is a clearly distinct and large group of mountain populations (together with the L1 population), a similar grouping of coastal populations (L2 and L3), and the separate status of the population from Wielkopolska National Park (L4). Interestingly there is discrepancy between results from clustering and Tukey's HSD test regarding population FH1, but results from dispersion of the studied population on the plane of the first two discriminant variables show that this and also L4 population are separate from all others. Also those results maintain a crucial pattern, with the division of mountain and coastal populations. It should be mentioned that in creating this particular pattern, needle length was also the most involved factor.

Comparative studies of Scots pine populations from two earlier common garden experiments (provenance trials) (Kórnik, Supraśl IUFRO 1982) showed that populations from the northern and southern limits of the range are characterized by shorter needles than populations from the centre (Androsiuk et al. 2011). Our result show that this is also partially true in much smaller, regional scale, with mountain and costal populations having shorter needles than the population from Wielkopolska National Park. An additional explanation is needed in the case of the L1 population, located on the southern slope of a grey dune in Słowiński National Park (Baltic Sea coast). This population is grouped together with mountain populations because of its short needles. This is due to the small average needle length, which is only $39.0 \mathrm{~mm}$, compared to $52.98 \mathrm{~mm}$ for a nearby population, L2 (the distance between them is approximately $1 \mathrm{~km}$ ), and $54.65 \mathrm{~mm}$ for the L3 population from the Vistula Spit. The probable explanation for the observed differences lies in the different edaphic conditions in the places where they grow. The response of pine to extreme habitat conditions by producing shorter needles is known (Niinemets et al. 2001; Urbaniak et al. 2003), and such conditions are present in the case of the L1 population (poor and sandy dune soil). The influence of stress on pine in this population also manifests itself in high values of skewness (Tab. 1). It is interesting because a similar trend was observed by Urbaniak et al. (2003) in the Chrobotkowy Bór population (Tuchola Forest), wherein as its explanation, strong selective pressure acting on the morphological traits of needles in both studied populations was postulated.

FH1 population from the Tatra foothills, as the one with the least consistent pattern of obtained interpopulational differentiation, also requires comment. Based on HSD Tukey's test for all morphological needle traits (Tab. 3), it was placed together with mountain populations, whereas cluster analysis puts it closer to coastal populations (Fig 3A), while a scatterplot of populations in the space of the first two discriminant variables indicates its significant separateness from other populations (Fig. 2). The proposed explanation for this situation may be related to the known relationship between the length of needles and the altitude of pine stands: the higher the altitude, the smaller the average length of needles (Zajączkowski 1936). In our study, this correlation was observed in populations from the Tatras, Pieniny and the Stołowe Mountains, but also the population from Puścizna, near Chyżne (FH1), growing on bog, in the Tatra foothills, also had one of the shortest needle lengths, and was hence grouped together with mountain populations. From other studies, it is known that short needles are characteristic of bog populations (Urbaniak et al. 2003), and therefore environmental conditions, such as poor soil and environmental stress factors in our study, have a decisive influence on needle length.

In our research, we investigated three typical mountain Scots pine populations: M1 (Tatra Mts.), M2 (a collective population from the Pieniny Właściwe Mts.) and M3 (Stołowe Mts.). We do not have any information as to whether there was any gene flow between populations of the Sudeten and Carpathian mountains during the last glacial maximum, and if there was, we have no information regarding its extent (Ralska-Jasiewiczowa 2004). The geographical distance between them is ca. $280 \mathrm{~km}$. We assume, therefore, that this convergence of living conditions - extreme, mountain climate (short vegetation period, low temperatures and snow cover) - is the primary causes of their similarity. Moreover, M3 population in the constructed dendrograms consistently shows a similarity to the much more distant L1 coastal population, and the probable explanation of this grouping was discussed above. 
It was not surprising, however, that we demonstrated clear analogies between the Tatra and Pieniny populations. Those populations also have a significantly weaker relationship with another mountain population, M3 (from Stołowe Mts.), and are completely separate from the FH1 population (from the Tatra foothill region) at the same time. These observations are consistent with the proposed hypothesis about the relict origin of those populations. However, in the literature, there is no agreement as to whether Scots pine could have survived the last glaciation in those stands, as was suggested by Staszkiewicz (1993), or whether it is a later relict from the early Holocene, as was reported by Obidowicz (1996). Nevertheless, Scot pine manifests a distinct and unique set of morphological characteristics on those sites, which we also managed to demonstrate in this work.

The most distinct from the others and at the same time very variable in terms of obtained patterns of interpopulational differentiation, is the population from L4 (Fig. 3A-3C). It originates from the strict nature reserve within the Wielkopolski National Park - Zalewy Nadwarciańskie, and its morphological characteristics of needles situate it as a typical lowland population (Urbaniak 2009). Other lowland, coastal populations - L2 from Słowiński National Park and L3 from the Vistula Spit, came from almost identical forest communities - fresh mixed coniferous forest - and therefore it seems that environmental conditions are mainly responsible for their similarity in morphological traits of needles (Mamaev 1972).

Table 5. Pearson correlation coefficients between studied traits of needles and geographic parameters

\begin{tabular}{|c|c|c|c|}
\hline Trait & Altitude & Latitude & Longitude \\
\hline NL & $-0.72^{*}$ & 0.55 & -0.40 \\
\hline NRF & -0.53 & 0.48 & -0.28 \\
\hline NSF & -0.07 & -0.12 & 0.60 \\
\hline NRC & -0.48 & 0.39 & -0.22 \\
\hline NSC & -0.00 & -0.19 & 0.53 \\
\hline SL & -0.12 & 0.10 & 0.03 \\
\hline SR & -0.18 & 0.17 & 0.08 \\
\hline
\end{tabular}

$* p<0.05$

Additionally we calculated the Pearson correlation coefficients (Tab. 5) between studied traits and geographic parameters and we discovered that values of all features decreases with increasing altitude, especially NL (statistic significant correlation) and a little less with number of stomata rows on the both sides of the needles (NRF; NRC). Values of these three traits decreases also if populations grow much less to the east, whereas number of stomata per $2 \mathrm{~mm}$ length on the both sides of the needles (NSF; NSC) increases, what means that eastern populations have got shorter needles, less rows with stomata but more stomata (so stomata are smaller and there are more in one line). On the other hand, northern (costal) populations showed opposite situation: they have got longer needles and more rows and less stomata.

Finally, it is very important and should be noted that needle length, as a trait with the greatest impact on interpopulational variation, is also the one with the greatest variation coefficient, and is thus strongly susceptible to any environmental modifications. Using more stable needles traits - those associated with stomata, which because of their low variability, are generally better indicators of genetic differences (Mergen 1958, Żelawski and Niwiński 1966, Urbaniak 1998, Woźniak et al. 2006) - dendrograms were also constructed. Although they reflect the main division axis of the studied populations: into mountain and lowland populations, and maintain particular similarity between populations considered to be relict - M1 and M2, they do not give unambiguous information about their place of origin.

\section{Conclusions}

In conclusion, our study shows a broader geographical pattern of the morphological variation of natural Scots pine populations in Poland. All of the studied traits proved to be useful in the analysis of interpopulational differences, especially in terms of their historical and environmental ties. Using them, we demonstrated the distinct character of following groups: mountain, lowland and coastal populations. Moreover, this data, when supplemented by the results of biochemical and molecular analysis, might be useful in further study of the history of this species in Poland, and in particular can be used to better explain the relationships within relict populations. It is important because their unique 
nature was clearly observed in our work. Furthermore, it would be very interesting for a follow-up study to look more closely into interplay between environmental variables and morphological traits, which we only touched upon in this study.

\section{ACKNOWLedgements}

This project was partly supported by the Polish National Science Centre under Grant number NN305 019140.

\section{References}

Androsiuk P., Kaczmarek Z., Urbaniak L. 2011. The morphological traits of needles as markers of geographical differentiation in European Pinus sylvestris populations. Dendrobiology, 65, 3-11.

Androsiuk P., Urbaniak L. 2006. Differentiation of Scots pine (Pinus sylvestris L.) populations in the Tatra mountains based on morphological needle characters. Biodiversity: Research and Conservation, 3/4, 227-231.

Białobok S. 1970. Rozmieszczenie w Eurazji (Distribution in Eurasia). In: Sosna zwyczajna Pinus sylvestris L. (Scots pine Pinus sylvestris L.) (ed.: S. Białobok). PWN, Warszawa-Poznań, 78-85 (in Polish).

Białobok S. 1970. Sosna w lasach Polski od późnego glacjału po czasy współczesne (The pine in Polish forests since the late glacial period). In: Sosna zwyczajna Pinus sylvestris L. (Scots pine Pinus sylvestris L.) (ed.: S. Białobok). PWN, WarszawaPoznań, 16-51 (in Polish).

Boratyński A. 1978. Sosna błotna (Pinus ulginosa Neumann) w rezerwacie Błędne Skały w Górach Stołowych [Pinus uliginosa. (Pinus ulginosa Neumann) in Błędne Skały in Stołowe Mountains]. Arboretum Kórnickie, 23, 261-267 (in Polish with English summary).

Boratyński A. 1993. Systematyka i geograficzne rozmieszczenie (Systematics and geographical distribution). In: Biologia sosny zwyczajnej (Biology of Scots pine) (eds.: S. Białobok, A. Boratyński, W. Bugała). Sorus, Poznań-Kórnik, 45-70 (in Polish).
Cheddadi R., Vendramin G.G., Litt T., François L., Kageyama M., Lorentz S., et. al. 2006. Imprints of glacial refugia in the modern genetic diversity of Pinus sylvestris. Global Ecology and Biogeography, 15, 271-281.

Dering M., Kosiński P., Wyka T.P., Pers-Kamczyc E., Boratyński A., Boratyńska K., Reich P.B., Romo A., Zadworny M., Żytkowiak R., Oleksyn J. 2017. Tertiary remnants and Holocene colonizers: Genetic structure and phylogeography of Scots pine reveal higher genetic diversity in young boreal than in relict Mediterranean populations and a dual colonization of Fennoscandia. Diversity and Distributions, 23, 540-555.

Irvine J., Perks M.P, Magnani F., Grace J. 1998. The response of Pinus sylvestris to drought: stomatal control of transpiration and hydraulic conductance. Tree Physiology, 18, 393-404.

Jasiewicz A. 1965. Rośliny naczyniowe Bieszczadów Zachodnich (The vascular plants of the Western Bieszczady Mts., East Carpathians). Monografie Botaniczne, 20, 1-332 (in Polish).

Mamaev S.A. 1972. Formy vnutrividovoj izmencivosti drevesnych rastenij (Forms of intraspecific variation of woody plants). Nauka, Moscow (in Russian).

Mantel N. 1967. The detection of disease clustering and a generalized regression approach. Cancer Research, 27 (2), 209-220.

Mergen F. 1958. Genetic variation in needle characteristics of slash pine and in some of its hybrids. Silvae Genetica, 1, 1-9.

Naydenov K.D., Senneville S., Beaulieu J., Tremblay F., Bousquet J. 2007. Glacial vicariance in Eurasia: mitochondrial DNA evidence from Scots pine for a complex heritage involving genetically distinct refugia at mid-northern latitudes and in Asia Minor. BMC Evolutionary Biology, 7, 233, https:// dx.doi.org/0.1186/1471-2148-7-233.

Niinemets U., Ellsworth D.S., Lukjanova A., Tobias M. 2001. Site fertility and the morphological and photosynthetic acclimation of Pinus sylvestris needles to light. Tree Physiology, 21, 1231-1244.

Obidowicz A. 1996. A Late Glacial-Holocene history of the formation of vegetation belts in the Tatra Mts. Acta Paleobotanica, 36 (2), 159-206.

Oleksyn J., Rachwał L. 1994. Wzrost europejskich populacji sosny zwyczajnej (Pinus sylvestris L.) 
w doświadczeniu proweniencyjnym SP-IUFRO-1982 w Puszczy Niepołomickiej (Growth of European Scots pine (Pinus sylvestris L.) populations in SP-IUFRO 1982 provenance experiment at the Niepołomice Forest). Sylwan, 9, 57-69 (in Polish with English summary).

Pawlaczyk E.M., Bobowicz M.A., Korczyk A.F. 2010. Zmienność trzech naturalnych populacji Pinus sylvestris L. z różnych siedlisk Puszczy Białowieskiej oszacowana cechami igieł (Variability of three natural populations of Pinus sylvestris L. from different sites of Białowieża Primeval Forest estimated using needle traits). Forest Research Papers, 71 (1), 83-92 (in Polish with English summary).

Peakall R., Smouse P.E. 2006. GENALEX 6: genetic analysis in Excel. Population genetic software for teaching and research. Molecular Ecology Notes, 6, 288-295.

Pyhäjärvi T., Salmela M.J., Savolanien O. 2008. Colonization router of Pinus sylvestris inferred from distribution of mitochondrial DNA variation. Tree Genetics and Genomes, 4, 247-254.

Ralska-Jasiewiczowa M. 2004. Late Glacial and Holocene History of Vegetation in Poland Based on Isopollen Maps. W. Szafer Institute of Botany, Polish Academy of Sciences, Kraków.

Staszkiewicz J. 1968. Badania nad sosną zwyczajną z Europy południowo-wschodniej i Kaukazu oraz jej stosunkiem do sosny z innych obszarów Europy, oparte na zmienności morfologicznej szyszek (Investigations on Pinus sylvestris from South-eastern Europe and from Caucasus andits relation to the pine from other territories of Europe based on morphological variability of cones). Fragmenta Floristica et Geobotanica, 14, 259-315 (in Polish).

Staszkiewicz J. 1970. Systematyka i zmienność (Systematics and variability). In: Sosna zwyczajna $P i-$ nus sylvestris L. (Scots pine Pinus sylvestris L.) (ed.: S. Białobok). PWN, Warszawa-Poznań, 55-77 (in Polish).

Staszkiewicz J. 1993. Sosna w historii naszych lasów (The pine in the history of our forests). In: Biologia sosny zwyczajnej (Biology of Scots pine) (eds.: S. Białobok, A. Boratyński, W. Bugała). Sorus, Poznań-Kórnik, 11-31 (in Polish).

Szafer W. 1949. Drzewa i krzewy. Ilustrowany klucz do oznaczania drzew i krzewów krajowych oraz obcych częściej hodowanych w Polsce (Trees and shrubs. An ilustrated key to determination of native and often cultivated alien trees and shrubs). PZWS, Warszawa (in Polish).

Urbaniak L. 1998. Zróżnicowanie geograficzne sosny zwyczajnej (Pinus sylvestris L.) z terenu Eurazji na podstawie cech morfologicznych i anatomicznych igieł (Differentiation of Scots pine (Pinus sylvestris L.) from the area of Eurasia on the basis of anatomical and morphological characters of needles). Adam Mickiewicz University Press, Poznań (in Polish with English summary)

Urbaniak L., Karliński L., Popielarz R. 2003. Variation of morphological needles characters of Scots pine (Pinus sylvestris L.) populations in different habitats. Acta Societatis Botanicorum Poloniae, 72 (1), 7-44.

Urbaniak L., Androsiuk P., Ślósarz M., Vončina G. 2006. Zróżnicowanie populacji sosny zwyczajnej (Pinus sylvestris L.) w Pieninach Właściwych na podstawie cech morfologicznych igieł (Differentiation of Scots pine (Pinus sylvestris L.) populations in the Pieniny Właściwe range on the basis of morphological needles traits). Pieniny - Przyroda i Człowiek, 9, 71-78 (in Polish with English summary).

Urbaniak L., Vončina G. 2008. Charakterystyka sosny zwyczajnej Pinus sylvestris L. z Sokolicy, Czertezika i Kazalnicy w cechach morfologii igieł (The characteristics of Scots pine (Pinus sylvestris L.) at Sokolica, Kazalnica and Czertezik peaks on the basis of morphological traits of needles). Pieniny - Przyroda i Człowiek, 10, 19-26 (in Polish with English summary).

Urbaniak L. 2009. Badania porównawcze cech morfonologicznych igieł populacji Pinus sylvestris L. z terenów Wielkopolskiego i Słowińskiego Parku Narodowego oraz Borów Tucholskich (A comparative study of morphological characteristics of the population needles of Pinus sylvestris L. from the area of Wielkopolska and Slowinski National Park and Tuchola Forest). In: Wielkopolski Park Narodowy w badaniach przyrodniczych (Wielkopolski National Park in natural studies) (eds.: B. Walna, L. Kaczmarek, M. Lorenc, R. Dondajewska). Adam Mickiewicz University Press, Poznań-Jeziory, 135-142 (in Polish). 
Woźniak T., Androsiuk P., Nowak D., Urbaniak L. 2006. The expression of morphological needles characters of Scots pine (Pinus sylvestris L.) populations growing in various habitats in Puszcza Notecka. In: Variability and Evolution - New Perspectives (eds.: W. Prus-Głowacki, E.M. Pawlaczyk). Adam Mickiewicz University Press, Poznań, 449-462.

Zajączkowski M. 1936. O południowej granicy zasięgu sosny pospolitej w Polsce i występowaniu sosny reliktowej w Karpatach polskich (About southern limit of the range of Scots pine in Poland and the occurrence of relict pine in the Polish Carpathians). Prace Komisji Nauk Rolniczych i Komisji Nauk Leśnych PAU, 20 (in Polish).

Żelawski W., Gowin T. 1966. Variability of some needle characteristics in Scots pine (Pinus sylvestris L.) ecotypes grown on the comparative plantation. $E k$ ologia Polska Seria A, 14 (17), 275-283.

Żelawski W., Niwiński Z. 1966. Variability of some needles characteristic in Socts pine (Pinus sylvestris L.) ecotypes grown in native conditions. Ekologia Polska Seria A, 14 (19), 301-308. 